\title{
SPOL IN JEZIK NA ROBU PAMETI: MED SLOVNICO IN IDEOLOGIJO
}

\section{Mojca ŠORLI}

Filozofska fakulteta UL, Inštitut za slovensko literaturo in literarne vede, ZRC SAZU

Šorli, M. (2019). Spol in jezik na robu pameti: Med slovnico in ideologijo. Slovenščina 2.o, 7 (2): $45-74$.

DOI: https://doi.org/10.4312/slo2.0.2019.2.45-74

Pričujoče besedilo je povzemanje in analiza javne razprave, do katere je prišlo po sprejetju 41. sklepa Senata Filozofske fakultete Univerze v Ljubljani z dne 25. aprila 2018 o novi spolni dikciji v fakultetnih pravilnikih in ki je nato ob zanimanju medijev potekala več mesecev, vrhunec pa dosegla pred približno enim letom, 23. oktobra 2018, na Okrogli mizi Jezik in spol na Filozofski fakulteti UL. Obenem je ob ponovnem vrednotenju izraženih stališč z nekoliko časovne distance prispevek poskus nadaljevanja razprave o spolnih kategorijah in ospoljenih identitetah ter androcentričnosti v jeziku. Poleg osvetlitve teoretskega ozadja, ki je (ali bi moralo biti) gonilo razprave, smo opravili tudi preprosto statistično analizo odzivov glede na zastopanost v medijih in zastopanost po spolu. V kvalitativnem delu analize nas je zanimalo predvsem, katere strokovne in ideološke (navidezne) opozicije so napajale posamezne retorike in diskurze, ki so obarvali razpravo.

Ključne besede: spolno občutljiva raba jezika, androcentričnost, diskurz

Moška oblika za oba spola ne izključuje žensk, kot trdijo zafrustrirane ženske, ki jim lastne notranje težave onemogočajo objektivno branje družbenih praks.

(V. V. Godina, Kvarkadabra 12. 7. 2018) 
Slovnično pravilna raba generičnega moškega spola $v$ jeziku odraža nereflektiranost $v$ pojmovanju in obravnavi spolov /.../. Zlasti $v$ diskurzu instanc oblasti je glede na mednarodno strateško pripoznano politiko enakih možnosti spolov in spolno senzitivne rabe jezika treba uveljavljati načine izražanja, ki zmanjšujejo ali obidejo androcentričnost.

(R. Šribar, Interne smernice za spolno občutljivo rabo jezika 2010)

\section{PREDGOVOR}

Ni naključje, da je kljub številnim nasprotnicam jezikovnega ukrepa, ki ga je sprejel Senat Filozofske fakultete Univerze v Ljubljani aprila 2018, med njegovimi podporniki več žensk kot moških, kar potrjuje med drugim statistična analiza odzivov javnosti v 3. poglavju tega prispevka. Pobude za večjo spolno enakost v jeziku prihajajo tipično iz ženskih aktivističnih skupin, prav tako je več žensk med raziskovalci spolnih reprezentacij in spolno občutljivega jezika (gl. npr. (bibliografijo v) Sczesny, Formanowicz in Moser, 2016 ter Hellinger in Bussmann, 2001). Nuja po refleksiji lastne pozicije tudi v jeziku je med ženskami bolj prisotna zato, ker so kot skupina družbeno deprivilegirane. Pa vendar, poleg vidnih raziskovalk in teoretičark reforme jezika, kot so intelektualke iz družb z bogato feministično tradicijo, na primer francoske (npr. Luce Irigarey, Hélène Cixous in bolgarsko-francoska semiotičarka Julija Kristeva), se moči jezika zaveda tudi Noam Chomsky, sicer pristaš racionalističnega pogleda na jezik, ki trdi, da je mnogo lastnosti jezika odraz hierarhičnih struktur in avtoritet v družbi, med njimi tudi sistema dominacije po spolu, vendar v jeziku samem ni nič, kar bi to zahtevalo (Olson in Faigley, 1991). Francoske feministke zato vztrajajo, da je treba zatiranje žensk razumeti prav z vidika jezika. Vsaka in vse reprezentacije, bodisi žensk ali moških (če se zaenkrat omejimo na binarni kontekst spola), so najprej vsajene v jezik, šele nato v politiko, kulturo, ekonomijo in zgodovino. To je najmanj ena možna interpretacija Donne Haraway (1991, str. 3), ki trdi, da je »slovnica zgolj politika z drugimi sredstvi «. »Za druge je feminizem to, kar enačimo z nesmiselnim in občasno bodisi zabavnim ali nadležnim vztrajanjem pri nadomeščanju nazivov, kot 
denimo v angleščini Mrs in Miss z $\mathrm{Ms}^{1}$ in drugih spolno zaznamovanih izrazov, npr. chairman s chair « (Hellinger in Bussmann, 2001, str. 157). Pa vendar ni težko razumeti, zakaj so ženske po vsem svetu posebej občutljive na spolske razlike pri poimenovalnih praksah in naslavljanju. Te so namreč pomemben pokazatelj družbenega statusa žensk. Predvsem pa, kar je bistveno tudi za slovensko diskusijo o spolu in jeziku, »želijo ženske same odločati o tem, kako bodo v jeziku reprezentirane« (2001, ibid.). Zapisi kot tile spodaj dokazujejo, da razvoj jezikovnih pravil nikoli ni bil ločen od kulture in družbenih, še zlasti vrednotenjskih vzorcev. Če tradicija slovenskih slovnic in (naravne) skladnje predpostavlja, da je »moški spol bolj naraven od ženskega « (gl. Orešnik, 2015, str. 50), pa gre član Francoske akademije, slovničar Nicolas Beauzée, leta 1767 še dlje: »Moški spol je plemenitejši od ženskega zaradi superiornosti moškega nad žensko.« Toda najbolj neposredno so s poglavji, ki sledijo, povezane besede še starejšega francoskega jezikoslovca, akademika z imenom Claude Fabre de Vaugelas, ki leta 1647 pravi takole: »Ker je moški spol plemenitejši, mora vedno prevladati v primeru, ko se znajdeta skupaj moški in ženski spol.«

\section{UVOD - RADIKALNI JEZIKOVNI AKTIVIZEM ALI (USTALJENA) PRIZADEVANJA ZA MANJŠO ANDROCENTRIČNOST JEZIKA?}

Razprava, ki jo je sprožil ukrep Senata Filozofske fakultete Univerze v Ljubljani (dalje ukrep FF UL) aprila 2018 z namenom prispevati k blaženju jezikovnih nesorazmerij po spolu, temelji v resnici na nesporazumu, ki je nastal najprej zaradi drobne nepozornosti predlagateljev in predlagateljic pri jeziko(slo)vni formulaciji intervencije - ta namreč dopušča interpretacijo, ki je ne bi smela, kar pokažemo v nadaljevanju - nato pa se v javnih izmenjavah zaradi njegovega nadaljnjega spregledovanja tako v pozitivnih kot negativnih odzivih na sklep razvil v bistveno sestavino stališč, ki so spremembi nasprotovala. Mimogrede, kako daljnosežen je lahko besedilni zdrs, ilustrira R. Močnik (2019, str. 355) s komentarjem o rabi izraza »spolno občutljiva raba jezika « (dalje SORJ). ${ }^{2} \mathrm{~A}$ prav v drobni, vendar ključni pomanjkljivosti, tj. pri ubeseditvi predlagane

\footnotetext{
1 Danes že tudi z $M x$.

2 »Sklep Senata FF Univerze v Ljubljani uporablja izraz »občutljiva raba jezika«, ureja pa »spolno občutljivo rabo jezika « (kar je kalk po anglo-ameriškem izrazu »gender sensitive«). Senat ni pojasnil, zakaj je uporabil splošno dikcijo, čeprav je uredil le posebno vprašanje.«
} 
jezikovne strategije oz., kot se je izkazalo, tvegani oz. presplošni uporabi besed »se nanaša «, ${ }^{3}$ se skriva vzrok za napačno interpretacijo predlagane spremembe v jezikovni dikciji fakultetnih pravilnikov. Pojasnitev tega dejstva je bila na okrogli mizi Jezik in spol na FF UL ${ }^{4} \mathrm{v}$ nekem trenutku poimenovana kot predmet »sholastične razprave« (Šribar, 2018a). Obenem pa se zastavlja vprašanje, ali je sploh mogoč ustrezno kratek in dovolj poveden zapis, do sedaj praviloma navajan »pod črto«, ki ne bi vodil v nesporazume. Bi bilo kaj bolj jasno, da ne gre za poskus normiranja, ampak za izrabo svobode pri izbiri jezikovnih sredstev s specifičnim namenom, če bi v sklepu zapisali »da lahko ženska oblika dikcije v pravilnikih zastopa tudi moško « (Muršič, 2018, poud. M. Š.)? Da je zapis sklepa lahko vir nesporazuma, se je pravzaprav izkazalo šele $v$ retrospektivi, po tem, ko so se zvrstili (negativni) odzivi, mnogi med njimi kot posledica napačne interpretacije. Ali drugače, zapisovalci sklepa bi ob jasnosti lastne namere težko predvideli možne učinke konkretne ubeseditve, ki je želela zgolj zrcaliti prejšnje stanje. Pokazalo se je, da na videz preprost obrat dikcije močno (simbolno) učinkuje predvsem kot jezikovno dejanje, ki pa je po svoji nameri prekompleksno, da bi ga lahko pojasnila zgolj kratka »opomba pod črto«. Občutek, da gre v razpravi bolj za (prestižno) tekmovanje diskurzov kot željo po zbliževanju stališč, navdaja z nelagodjem, krepi pa ga niz navideznih oz. lažnih opozicij, ki jih je mogoče izluščiti iz razprave in ki jih podrobneje naslovimo v 6. poglavju. Pred tem v 2. poglavju znova naslovimo jedrno vprašanje o generičnosti moškega spola, v 3. povzamemo rezultate krajše statistične raziskave o odzivih na ukrep FF UL, v 4. razpravljamo o jeziku in identiteti, v 5. se podrobneje posvetimo pojmovanju spolnih kategorij, sklenemo pa s 7. poglavjem, ki mu sledi epilog.

\section{NEZAZNAMOVANOST MOŠKEGA SPOLA}

Napačna predpostavka, na kateri se je izgrajevala diskusija, je namreč, da se ženski slovnični spol ipso facto uveljavlja kot generična, torej univerzalna

3 »SKLEP 41: Sprejme se naslednje določilo o občutljivi rabi jezika v pravnih aktih FF: 1. V vse pravne akte FF se v uvodni člen zapiše ena od naslednjih dikcij: Člen (številka) V pravilniku uporabljen ženski slovnični spol (študentka, učiteljica itn.) se nanaša na kateri koli spol. ALI Člen (številka) V pravilniku uporabljen moški slovnični spol (študent, učitelj itn.) se nanaša na kateri koli spol. 2. / .../ « (poudarek M. Š.) 
oblika. Nikdar ni šlo za namero posegati v jezikovni sistem, čeprav je branje spornega 41. sklepa v tem smislu, zlasti če to počnemo z nenaklonjenostjo, mogoče, saj se ne opredeljuje eksplicitno glede generičnosti slovničnih oblik, pa tudi ne njihove spolne specifičnosti. Pojasnilo, da gre za simbolno gesto ${ }^{5}$ in ne namero spreminjati slovensko slovnico, je prišlo v javnost relativno zgodaj (npr. Stabej, 2018a), a očitno ni imelo dovolj eksplanatorne moči, saj ni doseglo namena. Toda sholastična je bila kvečjemu razprava, ki tega pojasnila ne samo ni upoštevala, ampak ga ni niti dopustila. Če bi ga, bi ostala večina jezikoslovnih stališč zlasti nasprotnikov brez prave teže, saj so ta temeljila (in še temeljijo) prav na navedeni napačni predpostavki. ${ }^{6}$ Ob tem se glede na potek razprave implicitno zastavlja vprašanje, $\mathrm{s}$ katerim se aktivno ukvarja na primer tudi literarna kritika, namreč ali je vsako mnenje že tudi (strokovno) stališče? Ne glede na vse je treba za kakršnokoli smiselno nadaljnjo obravnavo ponovno poudariti, da je uporaba zvez »generična ženska oblika « ali »generična raba ženskega spola « ali »povzdignjenje ženske oblike v jeziku « ipd. v razpravi o jeziku in spolu posledica tega, da smo v omenjenem sklepu, ki teh pojmov ne uvaja in še manj predpisuje, preprosto prebrali preveč. Za kaj torej pri ukrepu FF UL sploh gre? Zgolj uporaba ženske oblike v danem kontekstu ne prekategorizira pojma nevtralnosti, ki v univerzalnem kontekstu domnevno pritiče moški obliki, že zato, ker ženska oblika v sprejetem sklepu ne pretendira k vseobsegajočemu, pač pa si - kot odkrito ženska oblika - zgolj jemlje prostor, v katerem konkurira moški obliki. »Cilj je okrepiti konkurenčnost s spolom povezanih diskurzov in narediti hegemonske diskurze, ki priplavajo na površje v jezikovnih strukturah, šibkejše« (Motschenbacher, 2016, str. 155). Kot je bilo pojasnjeno na okrogli mizi FF UL (Kalin Golob, 2018), ni nihče zapisal in tudi ne sugeriral, da je s sklepom Senata FF UL ukinjena generičnost moške slovnične oblike, ki jo zdaj kani na enako izključujoč način nadomeščati ženska generična oblika. Ker ne gre

5 Nikakor pa ne zgolj »simbolično« gesto, ki ima drug pomen in tudi konotacijo (prim. Marvin, 2018a).

6 »Ker smo z uvedbo nevtralne ženske oblike odvzeli splošno nevtralnost vključujoči moški obliki, so te osebe [transspolne] trajno potisnjene v t. i. »opombo pod črto « brez jasne jezikovne rešitve« (Marvin, 2018) ali »Senat fakultete, na kateri sem se trudil štirideset let, se je odločil, da sprejme pravni akt, v katerem bo do zdaj uveljavljeni maskulinum v nespolnostni vlogi za tri leta zamenjal s femininumom, ki naj prevzame nespolnostno vlogo« (Debenjak, Dnevnik 2018). 
verjeti v univerzalnost katerekoli slovnične oblike, je mogoče uveljaviti večjo jezikovno enakost zgolj in samo z izmenjevanjem obeh oblik, pri čemer bodo enkrat v prednosti moške, drugič ženske identitete. ${ }^{7}$ To je denimo v angleškogovorečih okoljih povsem običajna praksa - kar sicer ne pomeni, da je univerzalno sprejeta ali celo ponotranjena. A v mnogih govornih skupnostih in mednarodnih organizacijah že dolgo ni sporno, da izbira moškega slovničnega spola ni zgolj stvar slovničnega pravila, ampak stvar moškosti kot norme. ${ }^{8}$ Primerjave z vpogledi in praksami v tujih jezikih so na mestu, saj ne gre za jezikovnospecifična, temveč (jezikovno)politična vprašanja, čeprav so možne rešitve odvisne od taksonomske umeščenosti posameznega jezika glede na tipološke lastnosti. Obstajajo tudi številni psiholingvistični dokazi (npr. Erlich in King, 1998, str. 168; Gastil, 1990; Martyna, 1978; Moulton, Robinson in Elias, 1978; Wilson in Ng, 1988) o tem, da ob stavkih, kot je denimo »Ko študent vstopi v sobo, naj vzame izroček « ali »Vsi kandidati imajo na voljo 20 sekund za odgovor, « torej z moškim spolom kot generično obliko, prej pomislimo na moške kot ženske, čeprav je implicitna domneva, da gre za oba oz. vse spole. Novejše so na področju psiholingvistike raziskave v okviru obširne raziskovalne infrastrukture Marie Curie Initial Training

$7 \quad$ V tem drobnem odklonu oz. gesti solidarnosti so nekateri ugledni posamezniki uzrli nevarnost za katastrofično usodo slovenščine. Boris A. Novak (2018b) je opozoril, da se »ne igrajmo neodgovorno z jezikom, da se ne bi jezik poigral z nami in nas pustil neme in zgrožene pred nerazumljivim, neizrekljivim, neobvladljivim obličjem sveta «. Kar nekajkrat je bil v odzivih omenjen Orwell z implikacijo distopične prihodnosti, ki naj bi jo najavljal ukrep FF UL. Sicer z druge perspektive, a podobno Šribar (2018b) ne dopušča možnosti, da podpiramo ukrep ne zato, ker smo del elit, temveč kljub temu, da to nismo. Da smo lahko obenem podporniki ukrepa in (avtoričine) kritike znanstvenih politik.

8 Smernice in strategije za SORJ (ang. gender-fair, gender-sensitive ali gender-neutral language) so integralni del politik za naslavljanje enakosti spolov (ZN, Unesco, Evropski parlament idr.). SORJ se uvaja kot odgovor na strukturalne asimetrije v statusu spolov in kot del širših prizadevanj za odpravo spolnega stereotipiziranja in diskriminacije. Problemov SORJ se lotevajo tako na ravni nacionalnih držav kot posameznih univerz in institucij, $\mathrm{v}$ številnih so bile nedavno sprejete tudi radikalnejše strategije, ki uvajajo zelo konkretne rešitve, čeprav z različno stopnjo poseganja v jezikovno rabo (npr. nemški univerzi v Leipzigu in Potsdamu 2013). Na Švedskem je prišlo do uvedbe novega, spolno nevtralnega zaimka hen, v angloameriškem prostoru se že dlje v podobnih kontekstih uporablja zaimek they. Pobude za spremembe beležimo tudi denimo v Avstriji in na Poljskem (npr. Formanowitcz idr., 2015). Med odmevne primere sodijo civilnodružbene pobude za spolno bolj vključujočo rabo jezika v Franciji (npr. Sarrasin idr., 2012). 
(Language, Cognition, and Gender), ${ }^{9}$ ki raziskujejo povezave med SORJ ter spolnim stereotipiziranjem in diskriminacijo po spolu. Pri nas je spornost moške nevtralnosti ugotavljala že Komisija za ženske v znanosti v internih smernicah za občutljivo rabo jezika leta 2010. Pred tem so pod okriljem Službe Vlade Republike Slovenije za zakonodajo nastale nomotehnične smernice za področje pravnih predpisov (2004/2008/2018), še prej pa sta razpravo o enakosti spolov v jeziku po zgledu priporočil Unesca, Sveta Evrope in drugih evropskih institucij odprla I. Ž. Žagar in M. Milharčič Hladnik (1995, 1996) (za podrobnejši pregled dosedanjih smernic gl. Dobrovoljc in Stabej, 2019, str. 374-377). V Smernicah iz leta 2010 (Šribar) je zbranih nekaj konkretnih leksikalnih in skladenjskih napotil, ki sicer temeljijo na izrabi obstoječih jezikovnih sredstev, vendar so vsaj nekatera jeziko(slo)vno slabo utemeljena in povsem poljubna. ${ }^{10} \mathrm{Tu}$ bi z razpravo lahko zaključili, a namen prispevka je opraviti sintezo preteklih izpostavljenih stališč in analizirati ob tem vznikli diskurzni univerzum. Zlasti nekateri pogledi s filozofsko-sociološko-antropološkim ozadjem (npr. Močnik, 2018a, Šribar, 2018b) so s partikularno konceptualizacijo odprtih vprašanj prispevali k temu, da je ostal (vsebinski) spopad jezikoslovnih stališč, ki še kako obstaja, slabo osvetljen.

\section{3}

STATISTIČNO O SPOLU IN JEZIKU

Česar prav tako ne bi smeli spregledati, je dejstvo, da so kljub temu, da je bilo mnogo odzivov ${ }^{11}$ posledica tako nerazumevanja namere kot vsebine sklepa Senata FF UL, ukrepu nasprotovali ne le slovenistke in slovenisti (A. Vidovič Muha, A. Žele, S. Štumberger, K. Ahačič, J. Dular itd.), temveč denimo tudi

9 http://www.itn-lcg.psy.unibe.ch/content/index_eng.html

10 Med skladenjskimi napotki najdemo denimo, da »je [v] 'Tina, Maja in Švrk so šli na sprehod.' priporočljivo običajno sintakso razgraditi, tako da se diskriminatornemu pravilu izognemo (npr. /.../ 'Tina in Maja sta šli na sprehod, s sabo sta vzeli Švrka.').

11 Podatki temeljijo na gradivu oz. prispevkih s seznama, objavljenega na straneh Wikiverze (https://sl.wikiversity.org/wiki/Izra\%C5\%BEanje_spolne_nebinarnosti) pod uredništvom U. Ferrari in S. Štumberger (dostop 15. 9. 2019), ter dodatnih objav o tej tematiki v omenjenem obdobju na podlagi omembe FF UL. Prispevki z Okrogle mize Jezik in spol z dne 23. 10. 2018 niso posebej upoštevani, saj so bila mnenja sodelujočih vključena v statistiko preko predstavitve stališč v drugih medijih. Stališči R. Kuharja, dekana FF UL, in B. A. Novaka, predsednika Komisije za slovenščino v javni rabi, ki sta nastopala v vlogah predstavnikov institucije (Senat FF UL in SAZU) in kot pobudnika javne razprave, sta bili evidentirani po enkrat, čeprav sta ju v medijih pojasnila večkrat. 
splošna jezikoslovka (T. Marvin) in klasični filolog (M. Marinčič), kognitivni jezikoslovec (L. Marušič), poleg njih publicist (M. Crnković), pesnika in pisatelja (B. A. Novak, G. Vojnović), sociolog (R. Močnik), socialna antropologinja in feministka (R. Šribar), antropologinja (V. V. Godina), študentke in splošna javnost ter nenazadnje in hudomušno rečeno »tako slabo informirani dobronamerneži kot medijski mrhovinarji « (Muršič, 2018). Kljub sicer dobrodošli odprtosti razprave pa se je izkazalo, da je za trezen pogled in presojo nujen vsaj osnovni uvid v dejstva poststrukturalističnega (in postracionalističnega) sinhronega jezikoslovja kot tudi $\mathrm{v}$ dediščino spoznanj feminističnega jezikoslovja, ženskih študij ter sociolingvističnih in socioloških perspektiv na spol in jezik. Da v tej zadevi sicer ne spol ne področje oz. veda niso odigrali glavne vloge, je razvidno po drugi strani s seznama nekaterih podpornikov intervencije: jezikoslovke in jezikoslovci, tako slovenista in slovenistka (M. Stabej, V. Gorjanc, M. Kalin Golob) ter italijanistka, anglist, sinologinja in nemcistka (M. Ožbot Currie, G. Ilc, J. Rošker, I. Samide itd.) kot publicistke in publicist (R. Ivelja, P. Vidali, V. Humar, V. Jager), pesnik in pisatelj (A. Rozman Roza), sociologinje, opredeljene tudi kot feministke (V. Leskošek, M. Jogan, M. Antić Gaber), in sociolog (R. Kuhar), antropolog (R. Muršič), astrofizičarka (A. Gomboc) ter študenti in splošna javnost.

\subsection{Zastopanost medijev}

V najrazličnejših medijih, tako osrednjih javnih kot manjših ali institucionalnih, je bilo v času med 25. 4. 2018 (sprejetje sklepa Senata FF UL) in 26. 6. 2019 po naši evidenci objavljenih skupaj 94 prispevkov 73 različnih avtorjev in avtoric. Zaradi domnevno manjšega dometa obravnavamo obenem kot del celote in tudi ločeno 8 prispevkov, objavljenih na zasebnih platformah, ki jih ne moremo šteti za javne medije. ${ }^{12}$ Rezultati kažejo, da so se v diskusijo intenzivneje vključili konservativni oz. tradicionalistični in desno usmerjeni mediji, med katerimi po številu prispevkov (nikakor pa ne tudi po številu različnih avtorjev) prednjači Radio Ognjišče (7), sledijo Demokracija (6), Portal Plus (5), Reporter (4), Družina (3) in Nova24TV (2). Značilno za naštete vire je,

12 Ločeno smo evidentirali 8 avtoric, ki so objavile prispevek bodisi pod lastnim uredništvom bodisi na svoji lastni platformi (revija, blog, socialno omrežje): Perspectives, Domovina, Total Slovenia, Barbara4u2c/ Youtube, Leemeta, Facebook, Nadškofija Ljubljana, Pravna praksa. 
da ne predstavijo nobenega prispevka, ki bi ukrep Senata FF UL podpiral, ali prispevka, ki bi skušal biti nevtralen - niso torej poročevalci, temveč enoznačni in odkriti promotorji stališča »proti«. Med tiste vire, v katerih se pojavijo zgolj stališča proti, sodita še spletni portal Kvarkadabra in spletna revija Fokuspokus. Osrednji nacionalni dnevniki skušajo predstaviti različna stališča, vendar so med njimi v doslednosti precejšnje razlike: v Delu zasledimo 1 stališč ZA in 1 NEVTRALNO, 7 jih je PROTI. V Dnevniku jih je 6 ZA in 9 PROTI, kot kaže, je z 2 ZA in 2 PROTI najbolj uravnotežen dnevnik Večer. Relativno uravnoteženo sliko kažeta še Radio Študent (1 ZA in 1 PROTI) ter Mladina (3 ZA in 3 PROTI). V Primorskih novicah smo zasledili 1 prispevek ZA, med televizijskimi prispevki pa je stanje naslednje: RTVSLO 3 stališča ZA in 1 PROTI, NovaTV24 2 PROTI, POPTV (Preverjeno z A. Arko) pa je pripravila soočenje podpornikov in nasprotnikov različnih spolov, ki ga lahko označimo kot NEVTRALEN prispevek. ${ }^{13}$

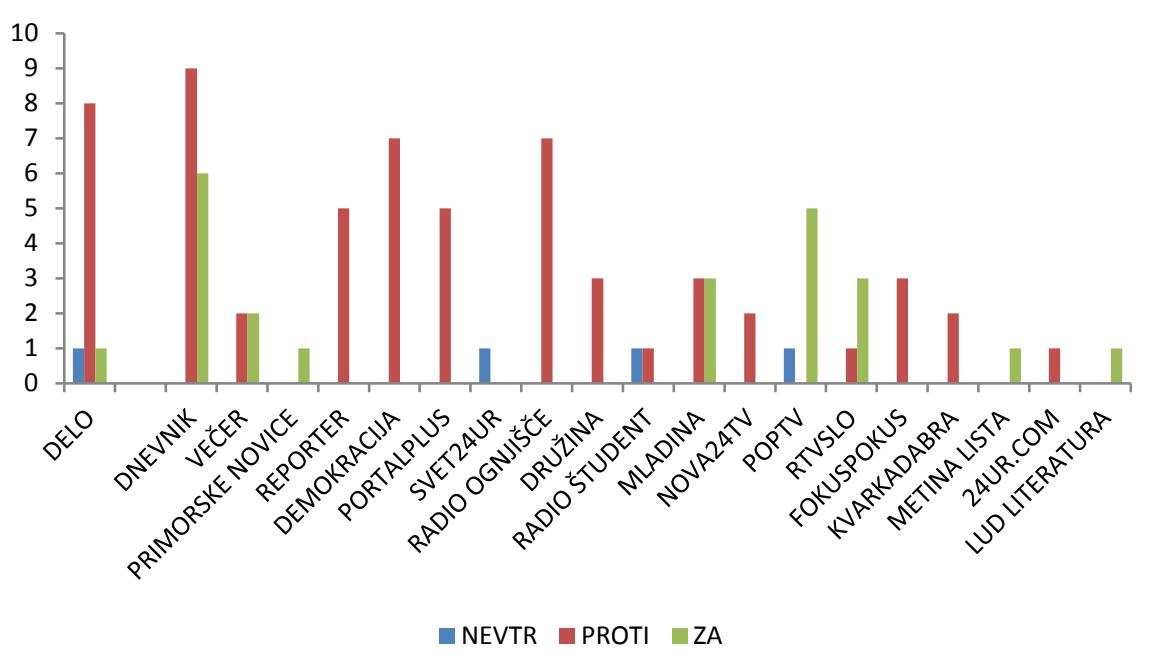

Slika 1: Distribucija mnenj glede na posamezne medije.

13 Kot nevtralni so bili beleženi prispevki, ki vsaj skušajo predstaviti obe plati argumentacije in se do vprašanja ne opredeljujejo osebno. Najpogosteje navajajo izjave posameznih razpravljalcev ali zgolj nizajo mnenja obeh strani. Nekateri tovrstni prispevki vsebujejo intervjuje bodisi z zagovornikoma nasprotujočih si stališč bodisi zgolj s predstavnikom ene opcije. Oboje smo uvrstili k posameznim intervjuvancem oz. intervjuvankam in jih označili - glede na argumentacijo - bodisi z ZA ali PROTI. 
Iz zgornjega prikaza je razvidno, da prevladujejo objave PROTI. 9 (od 21), torej 42,8 \% evidentiranih medijev je objavilo zgolj prispevke PROTI, le 3 oz. $14,2 \%$ pa zgolj prispevke ZA.

\subsection{Zastopanost spolov}

V medijih z uredniško politiko, ki jih lahko opredelimo kot javne, je v času med 25. 4. 2018 in 26. 6. 2019 prispevalo mnenje oz. stališče 65 različnih avtorjev in avtoric. Od teh je bilo $30(46,1 \%)$ žensk in 29 (44,6 \%) moških, pri šestih (pribl. $10 \%$ ) pa spol ni določljiv, ker je prispevek podpisan bodisi z inicialkami ali kot »uredništvo«. Razmerje po spolu med tistimi, ki so se izrekli o ukrepu, je bilo torej dokaj izenačeno, a proporcionalno gledano po spolih, je bilo med moškimi ukrepu precej več nenaklonjenih kot med ženskami: med moškimi je 23 (79 \%) tistih, ki so izrazili stališče proti, nevtralno stališče je izrazil eden (3,4 \%), naklonjeno stališče pa je izrazilo pet $(17,2$ \%) moških. Od žensk, na drugi strani, je bilo 17 (56,6 \%) tistih, ki so se opredelile proti ukrepu, 10 (30 \%) se jih je pozitivno izrazilo o ukrepu, tri (10 \%) pa so (kot poročevalke oz. novinarke) skušale ostati nevtralne. Sklenemo torej lahko, da je - relativno gledano - za dobrih 20 \% več moških kot žensk nasprotovalo ukrepu, hkrati pa dobrih 10 \% manj moških kot žensk ukrep podprlo. Če tej evidenci dodamo še 8 avtoric, ki so objavile svoj prispevek na lastni platformi, in beležimo skupaj 73 prispevkov, so razmerja nekoliko spremenjena: 38 (52 \%) žensk in 29 (39,7 \%) moških. Od vseh sodelujočih žensk je v tem primeru negativno mnenje prispevalo 25 (65,7 \%) žensk, pozitivno 10 (26,3\%) in nevtralno $3(7,8 \%)$.

Pri tem je treba opozoriti, da podatki ne govorijo o splošni dejanski podpori ukrepu med ženskami in moškimi, temveč zgolj o deležu podpore med tistimi, ki so se odločili javno oglasiti v zvezi z ukrepom. Glede na splošno slabo zastopanost žensk v medijskem govoru (prim. npr. ankete na Metini listi) ${ }^{14}$ je mogoče sklepati, da so se bile zaradi družbenih pričakovanj ženske manj pripravljene javno izpostavljati oz. »ustvarjati razumskost« (Jogan, 2018) tudi pri vprašanjih rabe jezika.

14 Metina lista: pregled deležev žensk-avtoric v tiskanih medijih 2016-2018 in v najbolj gledanih informativno-analitskih TV oddajah 2014-2016, gl. bibliografijo. 


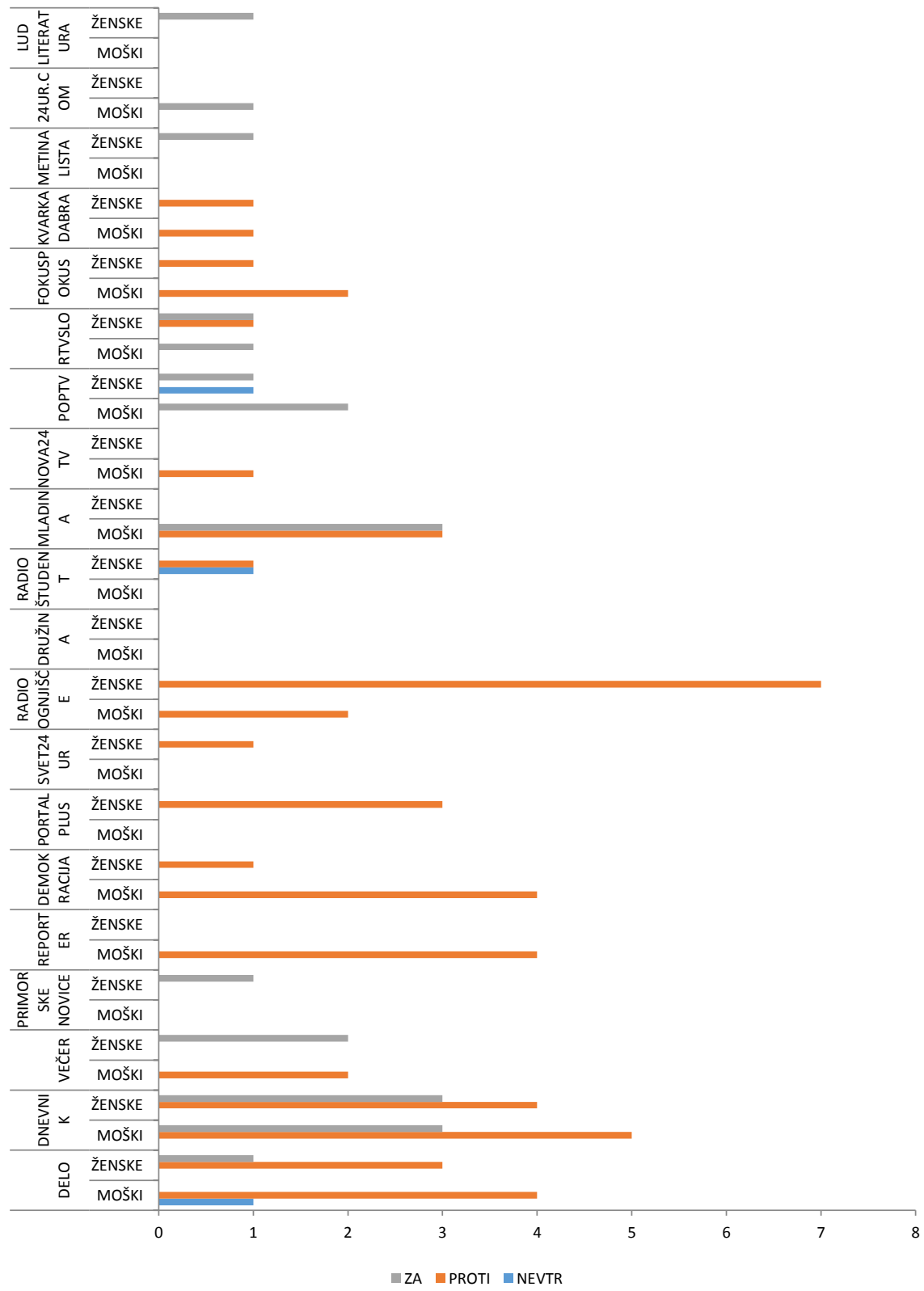

Slika 2: Distribucija mnenj glede na spol po posameznih medijih. 
V nadaljevanju bomo skušali različna stališča strukturirano povzeti in umestiti v mrežo temeljnih prepoznanih opozicij in ločnic, ki razpravi še naprej dajejo zagon in ritem. Če imamo občutek, da smo v slepi ulici, je to po eni strani zato, ker gre znotraj jezikoslovnega (ideološko-nazorskega) spopada za mešanje politike (rabe) jezika z jezikovnosistemskimi vprašanji, po drugi zato, ker je vprašanje spola in spolnih identitet kompleksno družbeno vprašanje, ki terja široko zastavljen interdisciplinarni pristop ob upoštevanju poststrukturalističnih premis tako feminističnih jezikoslovnih študij kot drugih področij raziskovanja spola. Tudi s tem, ko so napačno identificirali oz. površno povzemali jedrne opozicije, so nekateri novinarji dodatno dezorientirali javnost. Tako bi na primer na podlagi prispevka v Delu (Plahuta Simčič, 2018) neinformirani bralec lahko povsem napačno sklenil, da gre za spopad med jezikoslovci na eni strani in »ideologi « ter »pragmatiki « na drugi. Toda ne glede na nestrpnosti, ki jih je proizvajala razprava, lahko vidimo v njej veliko pridobitev ob spoznanju, da skupin, ki se ne najdejo v žensko-moškem spolnem binarizmu, torej transspolnih skupin, v prizadevanjih za bolj vključevalen javni diskurz ni mogoče več spregledovati. Izkazuje se, da so »manjšine«, ki imajo problem s heteronormativnostjo, precej bolj raznolike in tudi številčnejše, kot bi morda pod vztrajnim pritiskom heteronormativnega spolnega diskurza pričakovali. Sicer pa gredo ženske študije in študiji spolov še precej dlje, kot se podajamo v tej razpravi, ki je prostorsko, tematsko in teoretsko omejena. Morda nekoliko provokativno, a še kako povedno je na neki okrogli mizi dr. Alenka Zupančič (Filozofski inštitut ZRC SAZU) na vprašanje moderatorke, ${ }^{15}$ ali bi, če ne bi bila ženska, njena akademska kariera potekala kako drugače, na pol v šali odgovorila z vprašanjem: »Kako pa sploh veste, da sem ženska? « Ta odgovor, slej ko prej retorične narave, odlično ilustrira, kako kompleksen je v resnici problem nanašanja na spolno identiteto. Ni nujno le, da hkrati govorimo o slovničnih spolnih kategorijah in ospoljenih identitetah, ki zadevajo več vidikov spola, temveč prihajata poststrukturalistični feminizem (npr. Butler, 1993; Motchenbacher, 2010; Zimman, 2014) in kvirovsko jezikoslovje do pomembnega spoznanja, da je tudi »biološki spol « družbeno in diskurzivno konstruiran (Kern in Vičar, 2019, str. 416).

15 A. Tomažič na pogovoru o promociji dosežkov raziskovalk ZRC SAZU »ZRC je tudi ženskega spola« (20. maj 2019). 
Pa vendar, ker je v slovenskem jezikoslovju preizpraševanje nevtralnosti moške oblike še vedno subverzivno stališče, je pred uvedbo transspolnih pogledov $\mathrm{v}$ mainstream diskurza najbrž smiselno najprej vpeljati uveljavljene sodobne teorije o razmerju med jezikom in identiteto, med jezikom kot sredstvom komunikacije in jezikom kot sredstvom tvorjenja družbenih odnosov. Še danes je namreč v (vplivnem) delu slovenističnega jezikoslovja razširjeno prepričanje, da jezik ne posega bistveno v družbeno realnost, temveč da jo kvečjemu odseva, sicer pa da je jezik od uporabnika neodvisen abstraktni sistem z avtonomnimi razvojnimi zakonitostmi. ${ }^{16}$ Tudi iz vrst kognitivnih jezikoslovcev (gl. Marušič, 2018) prihaja argument proti sprejetemu posegu v jezikovno rabo, temelji pa na redukcionistični podmeni, da bi morala obstoječa razmerja med družbenimi skupinami po svetu bodisi potrditi ali zavreči možnost vpliva na to, da je dominantna družbena skupina $\mathrm{v}$ jeziku izražena kot nevtralna, pri čemer bi pričakovali, da so taksonomsko primerljivi jeziki podobno uvrščeni na lestvici spolne enakosti.

\section{TEORETSKO OZADJE}

\subsection{Jedro konceptualnih nesoglasij: pojmovanje kategorije spola}

V tem prispevku razumemo »spol « kot eno ali več od (vsaj) štirih ravni spolskih kategorij oz. "potez « (izraz po Kunst Gnamuš, 1994/95), glede na katere ločimo slovnični, leksikalni oz. leksikalno-semantični, referencialni in družbeni spol (gl. Hellinger in Bussmann, 2001, str. 7-11). Izraz »referencialni spol « razumemo dinamično, kot referencialno razmerje, ki jezikovne izraze povezuje z družbeno stvarnostjo, in ne kot biološko danost nanosnika. Da je ta raven razlikovanja med vidiki spola v jeziku nujna, kažejo denimo primeri, kot so otrok, oseba, dete itd., torej t. i. spolno nevtralni samostalniki, ki imajo vsak svoj slovnični spol, »naravni« oz. »biološki« spol pa je (leksikalno) nerazviden. Toda spol je bodisi »kodiran v odvisnosti od reference« bodisi od

16 Slovenska posebnost, ki najverjetneje vpliva na relativno konservativnost v pristopih do raziskovanja spola v jeziku, še posebej v slovenističnem jezikoslovju, je ta, da so bile tovrstne raziskave (v okviru ženskih študij in študijev spolov) institucionalizirane najprej na družboslovnih fakultetah, za razliko od denimo vzhodnoevropskih družb, kjer so se tovrstni študiji uveljavili praviloma najprej na jezikovnih ali humanističnih oddelkih (Antić Gaber in Kuhar, 2019, str. 113). To je pri obravnavi spola v jeziku zagotovo prispevalo k zaostajanju jezikoslovja za družboslovnimi vedami. 
slovničnih oblikoskladenjskih pravil, leksikalnega pomena ali »družbene položajskosti«, kar je v veliki meri odvisno od pragmatičnih dejavnikov (Kunst Gnamuš 1994/95). Čeprav tudi sama uporablja binarizem slovničnega in naravnega spola, O. Kunst Gnamuš, ki jo v podporo svojim tezam o generičnosti moške slovnične oblike pogosto navajajo privrženci in privrženke sistemskega pogleda na jezik (npr. Žele, 2019; Vidovič Muha, 2019), nanjo pa se sklicuje denimo tudi sociolog kulture R. Močnik (2019, str. 356) s trditvijo, da je »to [nevtralnost oz. univerzalnost moške oblike] mogoče znanstveno dokazati«, v svojem pogosto citiranem besedilu o spolu kot slovnični kategoriji na eni in potezi reference na drugi strani navaja sklepe, iz katerih je mogoče razbrati tudi močno zavedanje o obstoju »referenčnega « in družbenega spola in, pomembneje, celo (implicitno) kritiko obstoječega spolskega sistema (Kunst Gnamuš, 1994/95): ${ }^{17}$

Glede na dejansko referenco se $\mathrm{v}$ besedilu pojavi presežek oblik moškega spola in primanjkljaj oblik ženskega spola. Gospodarnost izražanja se dosega v škodo oblik ženskega spola. Lahko bi rekli, da oblikoslovno-skladenjska pravila in načela rabe ne omogočajo enakovrednega prikazovanja spolne razlike moški - ženska, temveč jo prikazujejo prek hierarhizacije.

Podrobno branje celotnega besedila vodi k zaključku, da sicer avtorica pristaja na slovnično oz. sistemsko določeni univerzalizem moške oblike, da pa se dobro zaveda številnih drugih razsežnosti, denimo psihološke in ideološko-politične, ki sooblikujejo jezik, in obenem samokritično priznava pomanjkanje dokazov, da je oblikoskladenjska moška nevtralnost zares mogoča (ibid.):

Na psihološko pa tudi ideološko-politično priostreno vprašanje, ali prikazovanje spolne razlike prek hierarhizacije oblik in pravil, s katerimi izražamo spol, vpliva na oblikovanje spolne istovetnosti ženske osebe, njene morebitne neenakovrednosti, v pričujoči raziskavi ni mogoče odgovoriti, saj ne vemo, kakšne zavedne in nezavedne učinke ima posredujoča vloga jezikovnih pravil pri prikazovanju dejanskosti in pojmotvornosti.

\subsection{Samostalniki za poimenovanje oseb}

Predpostavka v naši razpravi je sicer, da je skupina samostalnikov, ki zajema poimenovanja oseb, posebna z ozirom na kategorijo spola, saj ima vsaka

17 Povzeto po: https://www.jezikinslovstvo.com/ff_arhiv/lat2/040/77c02.htm 
oseba - za razliko od predmetov in pojmov - svojo lastno spolno identiteto, ki je zunanji opazovalec ali govorec ne more razbrati oz. jo določa zgolj na podlagi družbenih pričakovanj in stereotipov, kot že nakazano zgoraj. Seveda moramo ločevati med slovničnim in referencialnim vidikom spola, vendar je treba zlasti v primeru, ko gre za osebe, hkrati upoštevati tudi to, da gre za preplet obojega. To dejstvo predstavlja v družbi, ki se vse bolj senzibilizira v razmerju do reprezentacij spola $v$ javnem diskurzu, izhodišče za utemeljeno kritično razpravo o vzpostavljanju spolnih identitet skozi jezikovna sredstva.

Drži torej, da se »slovnični spol v jeziku ne ujema nujno z »biološkim « (dekle - jezikovno srednji ali ženski, biološko ženski spol)« (gl. Marvin, 2018a, 2018b), bi pa bilo obenem korektno opozoriti, da je povezava med slovnično in t. i. leksikalno opredeljenim spolom še posebej izrazita prav pri imenih za osebe, najbolj konsistentno pri sorodstvenih izrazih (deček, teta, boter, sestra). O »biološkem/naravnem « spolu kot jezikoslovni kategoriji takorekoč ne moremo (več) govoriti. ${ }^{18}$ Kot vemo, je spol celo v biološkem kontekstu nestalna kategorija, sicer odvisna tudi od kromosomov, fizioloških mehanizmov in hormonskega delovanja, vendar v kompleksnem prepletu z družbenimi pričakovanji in normami - medicina denimo aktivno posega $v$ to stanje in ga (na željo posamezne osebe) usklajuje (term. ustrezneje »potrjuje«) s posameznikovo percepcijo lastnega (družbenega) spola. Predmet diskusije so zato v resnici družbene konvencije, jezikovno oz. diskurzivno strukturiranje spola, in ne »naravne « danosti. Za zdaj puščamo ob strani transspolno perspektivo, pri čemer se zavedamo pasti spolnega binarizma.

\section{RAZNORODNOST NASPROTUJOČIH STALIŠČ - PREGLED}

Izmed omenjenih raznorodnih stališč in teoretskih izhodišč je mogoče izluščiti osnovna torišča, v filozofsko-teoretski perspektivi imenovana tudi »problemska polja« (Močnik, 2019, str. 355), iz katerih vznika diskurz o SORJ. Čeprav se zdi diskusija na prvi pogled binaristična, stališč ni mogoče razvrstiti

18 »Ker pa v realnem življenju spol ni zreduciran le na ženske in moške, kot nam je pripisan ob rojstvu, temveč je odvisen od mnogih dejavnikov, je zato pomembno, da $\mathrm{z}$ uporabo primernega in vključujočega jezika pokažemo, da se tega zavedamo ter tudi udejanjamo « (Drnovšek Zorko, 2019). In: »Izraz biološki je povsem odveč. Gre za spol, pripisan ob rojstvu, kar je termin, ki ga uporabljamo namesto izraza 'biološki spol' « (Transakcija, gl. seznam literature). 
vzdolž ene same dihotomije, saj se realizirajo v številnih (ideoloških) odtenkih. Vseeno pa je moč prepoznati vsaj naslednje ključne opozicije:

1. Na eni strani pogled, prevladujoč predvsem v tradicionalno strukturalistično naravnanem delu slovenistike, ki vidi v ukrepu FF UL (radikalen) poseg v jezikovni sistem slovenščine, na drugi prepričanje, da ukrep kot simbolna gesta ${ }^{19}$ ne posega v jezikovni sistem, temveč zgolj v jezikovno rabo oz. jezikovno politiko na področju enakosti spolov. Znotraj jezikovnosistemskega pogleda je mogoče ločiti med bolj ortodoksnimi prepričanji, da problem družbene neenakosti spolov ne izhaja iz jezikovne kategorije spola in ga zato tudi ni mogoče urejati s pomočjo jezika oz. skozi jezik, ter tistimi, ki problem prepoznavajo, a nasprotujejo vsakršni politično motivirani intervenciji v jezik, češ da je mogoče in treba problem SORJ reševati zgolj z obstoječimi jezikovnimi sredstvi, torej bolje izkoristiti jezikovnosistemske možnosti slovenščine. ${ }^{20}$ A. Vidovič Muha (2019) pa ob interpretaciji jezikovne politike kot ideologije uvede kar opozicijo med jezikovnim sistemom in ideologijo.

2. Naslednja opozicija je najlepše razvidna iz jezikovnega modela J. Tuldave (1998), zato spodaj navajamo shemo, ki podpira tudi stališče, da mora biti težišče v diskusiji o spolu in jeziku prestavljeno z jezika kot sistema na jezik kot (javni) diskurz (vedênjski vzorci oz. jezik kot družbena semiotika), kajti družbena razmerja so vpisana v jezik. Iz prikaza je razvidno, da ne moremo hkrati razpravljati o jeziku kot sistemu in jeziku kot diskurzu, saj sta v igri dve različni perspektivi. V skladu s prvo je jezik statičen produkt v območju potencialnega, druga pa odstira dimenzijo jezika kot dinamičnega procesa v območju dejanskega.

Jezikovne izbire, ki določajo posamezne diskurze, so sicer odločilne na dveh ravneh, v razmerju do drugih govorcev in v razmerju do sebe: torej, 1) kakšen jezik uporabljamo, ko govorimo o drugih, in 2) kako z jezikovnimi izbirami določamo sami sebe. Pri tem, kot kažejo študije,

19 Kot je bil opredeljen ukrep s strani članov Delovne komisije, ki je pripravljala strokovno podlago za ta ukrep (npr. Stabej, 2018a).

20 Takšna prepričanja je zaslediti tudi pri feministični avtorici (gl. Šribar, 2018b). 


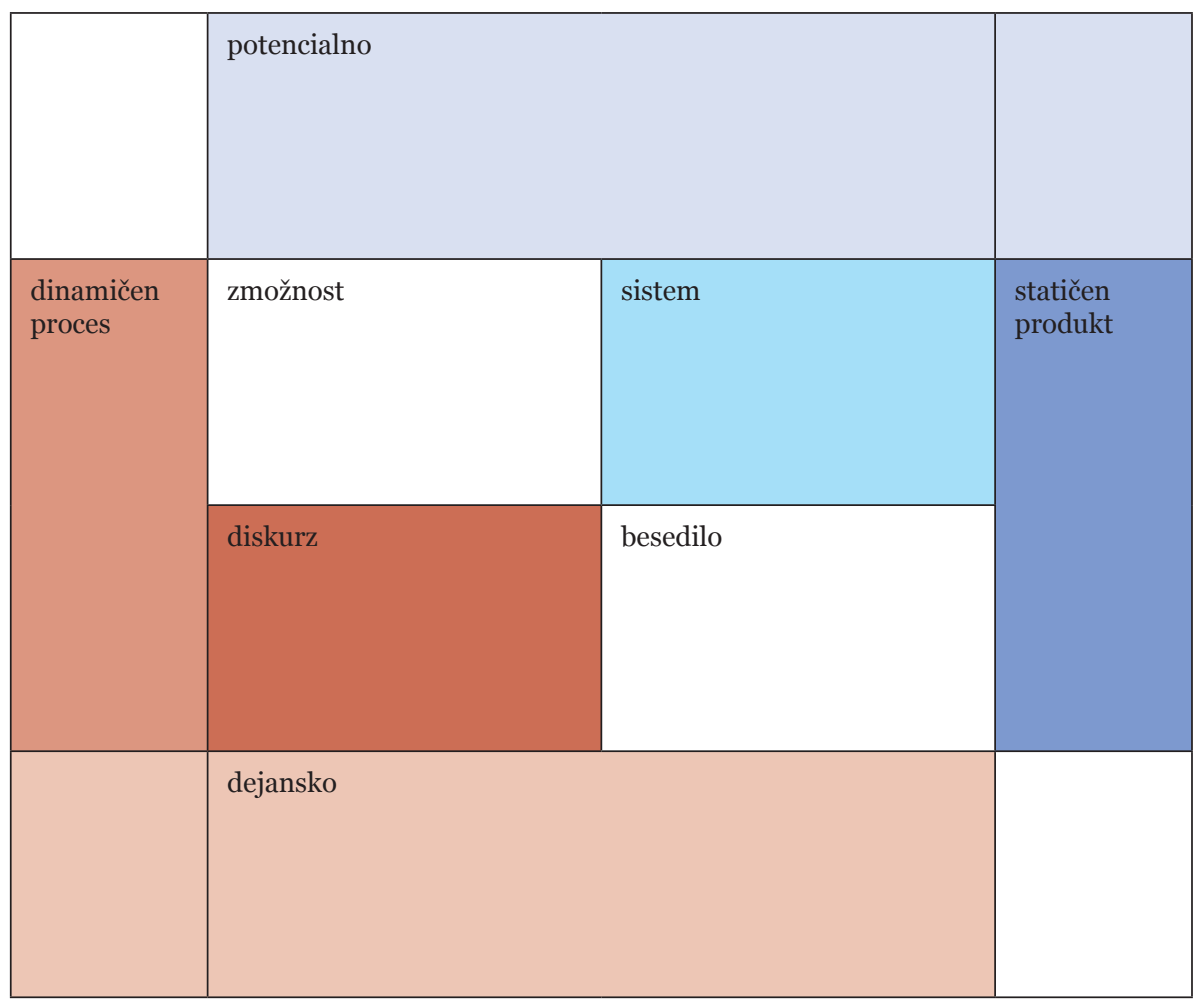

Slika 3: Jezikovni model po Tuldavi (1998, str. 13 ff.).

gre za izbire ne zgolj na področju leksike in skladnje, ampak tudi denimo v fonetiki in na ravni diskurzivnih vzorcev (gl. npr. Holmes, 1997a, 1997b).

3. Kot posledica izvornega nesporazuma je po svoji paradoksalnosti najgloblje zabredla diskusija o tem, ali je ukrep FF UL vključevalen ali izključevalen. Očitek o izključevalnosti, ki je uspešno polnil medijska poročila $\mathrm{z}$ bombastičnimi naslovi, je poenotil nasprotujoča stališča sicer izrazito različnih provenienc, ki so sovpadla v deklarirani kritičnosti do sodobne kapitalistične družbe (npr. Šribar, 2018a; Vuk Godina, 2018; Močnik 2018a). Podpornikom je bilo sporočeno, da s prizadevanji za SORJ podlegajo najhujšim diskriminatornim praksam kapitalizma. V tem sklepu sta se - kar je zanimiv precedens - morali strinjati celo avtorica feminističnega navedka $\mathrm{v}$ uvodnem delu tega 
prispevka in avtorica njegove antiteze, kar je dokaz, da je (lahko) tudi pozni kapitalizem svojevrsten »prazni označevalec«. V isti sapi je namreč očitno mogoče opredeliti ukrep tudi kot dejanje upora proti »govorici kapitalizma (npr. Jager, 2018). Morda velja ponovno poudariti, da izključevalnost/vključevalnost ni stvar jezikovne oblike same po sebi, temveč njene rabe, predvsem pa percepcije pomena, ki ga ta oblika projicira v danem besedilnem in družbenem kontekstu. Zato se mora zdeti v kontekstu prizadevanj za SORJ deplasiran očitek o izključevalnosti, saj je v 41. sklepu FF UL izrecno rečeno, da je namen uraunotežiti obe rabi. Kljub naporom kritikov, da bi vzpostavili med njima razliko, gre za proces, analogen uvedbi spolnih kvot v politiki. Ob tem ko so nekateri ukrepu priznali dobronamernost, so mu mnogi $\mathrm{v}$ celoti odrekli legitimnost namena, kar je dalo nasprotovanjem $\mathrm{v}$ tej točki pridih pavšalnosti.

4. Nekatera izražena prepričanja vidijo v intervenciji Senata FF UL problem predvsem v poskusu prenovitve formalnopravnega diskurza (npr. Močnik, 2019), kjer je dosedaj prevladovala dikcija moške generičnosti z običajno opombo pod črto o tem, da se moška oblika nanaša tudi na ženske in vse ostale. Ta praksa je sama dokaz, da niti v pravnih aktih od uporabnic nismo nikoli zares pričakovali percepcije moške slovnične oblike kot oblikoslovno in skladenjsko generične. Namesto tega se je uveljavil dogovor, torej konvencija o generičnosti moške slovnične oblike, kot konvencija pa je koncipiran tudi sporni ukrep. Kalin Golob in Lengar Verovnik (2019, str. 386) izpostavita, da »[n]obenega posebnega razloga ni, da bi bila tovrstna rešitev [namreč, da bi to veljalo tudi za žensko obliko] za pripadnike moškega spola kaj bolj nerazumljiva, kot je za pripadnice ženskega spola sedanja praksa «. Še drugače, obstoječe jezikovne strategije ukrep v ničemer ne spreminja na način, ki bi bil relevanten ali celo sporen s pravnoformalnega vidika. Zdi se, da gre na tej točki za vzročno-posledično zamenjavo, saj prenovitev formalnopravnega diskurza ni cilj, temveč posledica prizadevanj za večje spoštovanje enakosti spolov v jeziku. Iz tega nadalje izhaja, da zgolj zato, ker se je intervencija zgodila $v$ formalnopravnem besedilu, ni mogoče zaključiti, da se je diskusija odvijala prvenstveno 
v opoziciji med poljem jezikovnega sistema in "problemskim poljem pravnega sistema « (gl. Močnik, 2019, str. 356). ${ }^{21}$ Po drugi plati je problematiziranje formalnopravnega diskurza zelo na mestu, saj je za uradniški jezik in zakonodajnopravna besedila značilna raba jezika, ki je izrazito določena z močjo institucije v razmerju do posameznice ali posameznika, ki se ji je dolžan podrejati. V tem smislu ga je še kako vredno opredeliti in obravnavati kot »problemsko polje« pri doseganju enakosti spolov. Ali kot pravi M. Stabej (2018b), »pravnoformalni diskurz je že sam po sebi nasilje nad realnostjo«.

5. Še ena opozicija, ki je pravzaprav navidezna, obstaja po zaslugi protiargumenta, da ni mogoče posegati v jezik mimo njegove dejanske rabe. ${ }^{22}$ To seveda drži za velik del merljivih jezikovnih pojavov in večino situacij, vendar je politična intervencija v jezik nekaj, kar se temu načelu po definiciji upira. Cilj tu ni ne opisovati ne normirati

21 Ta opozicija je dokaj umetna v kontekstu razhajanj, ki niso predvsem teoretska, temveč praktično-jezikoslovno in sociolingvistično utemeljena v jezikovnem aktivizmu. Obenem se zdi predaljnosežen tudi sklep, da gre pri ukrepu predvsem za politiko identitet, ki ne odpravlja diskriminacije, ampak jo s prevzemanjem kapitalistične liberalne ideologije in principov drobljenja družbe še poglablja (Močnik, 2019; Vuk Godina, 2018). To drži zgolj pogojno, če razumemo prizadevanje za enakost spolov kot »žensko « gibanje in ne kot to, kar v resnici je - družbeno gibanje. Problematizirana pa je seveda - tako v jeziku kot sicer - prav strukturiranost »univerzalnega «, saj vse kaže, da je neposredno vezana na družbeno moč. Spomnimo se tudi, da je bilo feministično gibanje, s katerim je od začetka tesno povezano gibanje LGBT, ob vsaki pobudi za spremembe deležno očitkov, da je treba najprej rešiti druge, pomembnejše probleme, ki so bolj univerzalne narave (npr. Jalušič, 2002, po Antić Gaber in Kuhar, 2019, str. 103). Prav zato bi bilo, če je treba poskuse feministične intervencije v jezik obtožiti, da »spodnaša[jo] abstraktni univerzalizem, dosežek buržoazne revolucije. /.../ « (Močnik, 2019, str. 358), mogoče enako - ad hoc/spreobrnjeno - tudi te očitke interpretirati kot ostaline hegemonih moškosrediščnih diskurzivnih praks, pa čeprav zavezanih »dosežkom buržoazne revolucije« (ibid.). Prav z nepriznavanjem, da gre pri zavzemanju za enakost spolov za univerzalizem, ki opominja na dosežene norme univerzalnosti človekovih pravic, priznavamo, da obstaja razlog za upor. V odpiranju diskusije o raznoterosti spolnih identitet in preseganju spolnega binarizma pa gre morda celo za prve znake v smeri ukinjanja (referencialnosti) spolov kot relevantne družbene kategorije in s tem nov progresivni univerzalizem?

22 Ta ni, kar Šribar napačno pojmuje kot »vse, kar v realnosti lahko ubesedimo in to tudi storimo« (2018b), temveč prav nasprotno. Dejanska oz. realna raba je le tisto, kar dejansko je bilo ubesedeno, po možnosti čim večkrat, to pa nam o jeziku lahko pokažejo le empirični podatki. Napačna je zato izpeljava, da bi uveljavitev »realne rabe« pomenila »vzpostaviti kot institucionalno normo vse, kar se v govoru da izvesti«. 
jezika, temveč v jezik kot družbeno vedênje vnesti potencialno transformacijo z ambicijo prispevati k preobrazbi družbenih odnosov. Ne gre za spreminjanje slovničnih pravil, pa tudi ta so nenazadnje v kompleksnem prepletu s težnjo po reprezentaciji (referencialnega) spola (Kunst Gnamuš, 1994/95). Razumljivo je, da je korpusnojezikoslovno raziskovanje v tej točki omejeno, saj omogoča uvid v gola dejstva (aktualne) jezikovne rabe, ne pa tudi v to, kaj o neki konkretni rabi mislijo in čutijo govorci in govorke. Za razmisleke o v jezik vpisanih družbenih razmerjih je to seveda ključno, zato se je v nekaterih primerih bolj smiselno osredotočiti na analizo (zlasti normativnih) slovarjev in/ali na eksperimentalne študije, ki razkrivajo percepcijo govorcev in poslušalcev.

6. Naslednja (prav tako navidezna) opozicija v diskusiji je med domnevno predpisovalnostjo ukrepa in potencialnim anormativizmom, ki naj bi omogočal »subjektivn[o] odločanj[e] o ustrezni jezikovni rabi kljub morebitnemu neuspešnemu sporazumevanju « (Smolej, 2019, str. 183). Kot smo izpostavili drugje (Šorli, 2018a), je ključno spodbujanje k uporabi različnih strategij, odvisno od vrste besedila oz. žanra ali sporazumevalne situacije, konteksta, naslovnika in namena besedila, nenazadnje od tega, koliko želimo spol izpostaviti. Jezikovna norma se bo še naprej uveljavljala, dopolnjevala in korigirala skozi rabo. Na tej točki se pridružujemo stališču, naj bo govorec »tisti, ki pragmatično presodi, katera jezikovna in nejezikovna sredstva bo uporabil in na kakšen način, in navsezadnje tudi, ali je raba izbranih jezikovnih sredstev ustrezna oz. neustrezna (tudi hotena) « (Smolej, 2019, str. 183), pri čemer ne vidimo nič spornega $\mathrm{v}$ svobodni in odgovorni izbiri jezikovnih sredstev bodisi posameznika bodisi skupnosti ali celo institucije, ki uporablja jezik v skladu s svojimi lastnimi prepričanji, standardi in ideološkimi nazori (jezikovna mikropolitika, gl. Kalin Golob in Lengar Verovnik, 2019). Ob vseh teoretskih razmislekih ne smemo pozabiti, da izhaja pobuda za ukrep s strani Senata FF UL iz zelo praktičnih oz. operativnih problemov, povezanih z zapovedano rabo moške oblike kot generične. Kot denimo v javni upravi, kjer se uslužbenka ob napotilu, da je moška slovnična 
oblika vsevključujoča, sprašuje, kako oblikovati besedilo, namenjeno vzgojiteljicam in (zelo redkim) vzgojiteljem tako, da ne bo, v najboljšem primeru, izpadlo smešno, v najslabšem pa žaljivo in izključevalno do žensk, ki predstavljajo v tem poklicu odločno večino. Tega problema ne more rešiti besedotvorno bogastvo slovenščine, ker - tako kot $\mathrm{v}$ večini primerov - ne gre le za probleme poimenovalnosti, temveč spolno zaznamovanega naslavljanja.

7. Med drugim je bilo ob pobudi Senata FF UL izpostavljeno kot problematično tudi izključevanje drugih spolov iz binarno zasnovane koncepcije spola, torej neupoštevanje transspolne optike, čeprav - pomenljivo - ta kritika ni prihajala predvsem s strani podpornikov transspolno usmerjenih jezikovnih politik (gl. Drnovšek Zorko, 2019). Zdi se, da so ti razumeli razpravo v osnovi predvsem kot pobudo za denaturalizacijo heteronormativnega spolnega diskurza. Predvsem kritiki ukrepov za odpravljanje neenakosti pa so želeli v predlogu prepoznati novo diskriminacijo in ga s tem razvrednotiti.

8. Kot opozicijo je mogoče prepoznati tudi očitke o domnevni avtoritarnosti ukrepa na eni in domnevno antiavtoritarnostjo upiranja ukrepu na drugi strani. Ta opozicija, ki je po nepotrebnem razgrela razpravo, je morda še najbolj problematična od vseh, saj je po svojem bistvu avtoritarno prav s privilegirane pozicije odrekati pravico do upora tistemu, ki je prisiljen bivati v deprivilegirani.

9. Nenazadnje je mogoče pogledati na usmerjenost argumentov tudi s političnega stališča glede na to, kje so bila objavljena mnenja in kakšna retorika je bila pri tem uporabljena. Čeprav odpora nikakor ni mogoče omejiti zgolj na konservativne in tradicionalistične medije, je bila po pričakovanjih intenziteta nasprotovanj v teh večja in bolj konsistentna kot $\mathrm{v}$ bolj levo usmerjenih in progresivnih medijih, predvsem pa je bil v njih bolj izrazit šovinistični, celo sovražni govor. Eden zanimivejših vidikov razprave je prav negiranje ali v najboljšem primeru marginaliziranje tega dejstva, še posebej na strani tistih nasprotnikov ukrepa, ki jih sicer prepoznavamo kot libertarne in progresivne. 
10. Na družbenonazorski ravni bi bilo načeloma mogoče iskati vzorce ujemanja med nasprotniki ukrepa in verjetjem $\mathbf{v}$ jezik kot primarno kulturno in nacionalno institucijo ter podporniki ukrepa in koncipiranjem jezika kot neodtujljivega dela posameznikove avtonomije in (spolne) identitete. Tu prihaja do napetosti zlasti med posamezniki ali skupinami, ki nastopajo s pozicije jezikovne avtoritete, in tistimi, ki se takšnim avtoritetam upirajo.

\section{SKLEP}

Odzive na sklep Senata FF UL z dne 25. aprila 2018 lahko glede na njihovo vrednotenjsko naravnanost opredelimo vsaj z naslednjimi splošnimi diskurzivnimi oznakami: katastrofizem, znanstvenost in nepristranskost, upor ter etična doslednost. Nekateri posamezniki in skupine so v ukrepu uzrli nevarnost za usodo slovenščine, zato so izbrali diskurz katastrofizma. Sem lahko štejemo retorike nekaterih posameznikov in posameznic, ki so se posebej aktivno javno angažirali. Zanimivo je, da je ta diskurz našel podporo ne le $\mathrm{v}$ javnem mnenju, temveč $\mathrm{v}$ manjši meri celo v sicer progresivnem feminističnem diskurzu, ki je intervencijo obsodil na podlagi, kot smo pokazali, »nadinterpretacije « sklepa. Zlasti del slovenistične stroke je igral na karto znanstvene rigoroznosti in »nevtralnosti « in vztrajal pri striktnem ločevanju jezikovnega sistema od jezikovne vedênja, nasprotno temu pa je del slovenistov in zlasti družboslovne stroke videl poseg v jezikovno rabo kot prizadevanje za šibitev moškosrediščnosti jezika in javnega diskurza. Skozi to optiko niso ključni problem spolnega $v$ jeziku izzivi poimenovalnosti, temveč spolno zaznamovanje simbolnega, slednje pa je, čeprav izraženo na različne načine, enako problematično v različnih jezikih (gl. npr. Hellinger in Bussmann, 2001). Diskurz, ki se oplaja v spoznanjih poststrukturalističnih pristopov k jeziku, so nasprotniki ukrepa večinoma razumeli kot radikalno stališče, ki želi nasilno poseči v tradicijo in »naravnost « obstoječega. Med oznakami zanj so se pojavili izrazi kot »orwellovski, norost, radikalni feminizem, sramotno poniževanje slovenskega jezika, ideologija, zmešnjava, jezikovni prevrat «itd. Poleg tega se je na obeh straneh vzpostavil tudi diskurz etične doslednosti, čeprav je v medijskem poročanju več teže dobil argument nasprotnikov, češ da gre za novo izključevanje. V veliki meri spregledano je bilo opozarjanje, da gre za nespoštovanje različnosti in za pravico družbeno šibkejših skupin 
do preizpraševanja kulturnih samoumevnosti. Tem diskurzivnim podlagam bi morali pridružiti vsaj še nestrpnost in sovražni govor v javnih odzivih in kritiko takšnega govora, ki žal nista postala vsebinski del razprave, čeprav bi morala, saj je prav nezmožnost spoštljive razprave najzanesljivejši znak, da neenakost zares živimo - tudi in še posebej v jeziku. Če bi želeli razumeti paradokse, ki so nastali ob proliferaciji nasprotovanj z izvori celo v diametralno nasprotnih idejnih zastavitvah, bi se morali vrniti povsem na začetek in ponovno nasloviti strategijo in namero sprejeta ukrepa. Po drugi strani veliko pove tudi dejstvo, da so zlasti negativni odzivi v okoljih, kjer potekajo sorodne razprave (gl. 2. poglavje, op. 10), utemeljeni takorekoč na identičnih podmenah, strahovih in pomislekih kot v Sloveniji. V tej luči so videti drugače celo skrajne interpretacije, ki omenjeni sklep označujejo za avtoritarno dejanje, dekret, ali ga denimo vzporejajo s fašističnimi jezikovnimi intervencijami (gl. Marinčič, 2018).

Strinjati se moramo, da je razumno in na spremljanju dejanske rabe utemeljeno normiranje jezika potrebno. Toda normiranje jezika ni bilo predmet razprave, in glede tega iz sprejetega 41. sklepa ne izhaja nič, pač pa to, da je (politična) izbira v jeziku, posebej kadar gre za preprečevanje reprodukcije obstoječih asimetrij, dovoljena in upravičena - še posebej ob upoštevanju premis poststrukturalističnih pristopov k jeziku, ki so v našem prostoru ( ̌̌e) relativno neznani. Pač pa so bile predmet razprave prakse za bolj vključevalno rabo jezika, v katero dnevno posegamo vsi, kaj in kako se bo dejansko uveljavilo, pa je stvar kompleksnih, ne le jezikovnih, temveč tudi družbenih procesov. Ali drugače, imamo pravico opredeljevati se do purizma in jezikovnih napak, do jezikovnih konvencij, do tiranije »lepega jezika « kot izrazito subjektivne in antiznanstvene kategorije, do funkcijskih in socialnih zvrsti jezika in vseh pritiskov zlasti jezikovnih avtoritet s pozicij moči.

\section{EPILOG: O ČEM JE V RESNICI GOVORA?}

Nujno je poudariti, da niso pobudniki sklepa in njegovi podporniki del tistih elit, ki že dolgo in vztrajno normirajo jezikovno rabo. V enem samem partikularnem ukrepu na mikroravni so prepoznali avtoritarnost in »dekretarstvo « prav tisti, ki imajo kot institucija, uradno pooblaščena za kodifikacijo slovenščine (na makroravni in od zgoraj navzdol), nesorazmerno moč pri 
uravnavanju jezika v javni rabi. Delovanje povezane institucije, kot je denimo Komisija za javno rabo slovenščine pod okriljem Slovenske akademije znanosti in umetnosti, prav tako in še bolj utrjuje pozicije moči v razmerju do posameznikove (javne) rabe slovenščine. Toda vzporedne procese in analogne situacije je najti tudi v številnih drugih govornih okoljih. Tudi Francoska akademija denimo nasprotuje t. i. feminizaciji francoščine, vendar so se v zadnjih dveh desetletjih kljub nasprotovanjem zgodili mnogi premiki v prid zmanjševanju neenakosti. Jezik je kot pomembno semiotično sredstvo ena od pomembnih družbenih institucij in s tem ključno prizorišče boja za enakost, ki mora biti odprto za aktivistične intervencije. Če upoštevamo, da je bilo načelne podpore za večjo vključevalnost jezika in enakost spolov v jeziku precej tudi na strani nasprotnikov, in če bi sprejeli še argumente, ki dokazujejo, da ukrep Senata FF UL ne posega v jezikovni sistem, potem smo že občutno skrčili tisto, kar se je na vrhuncu razprave zdelo kot nepremostljiv prepad med zagovorniki in nasprotniki ukrepa, sprejetega v aprilu 2018. Slovenščini se ni in se ne bo zgodilo prav nič, se je pa zato - upamo - zgodilo veliko s prebujeno pozornostjo do spolno občutljive jezikovne rabe.

\section{LITERATURA}

Ahačič, K. (2018). Janez Novak, študentka slovenščine. Delo (27. 5. 2018).

Dostopno prek http://www.delo.si/novice/slovenija/janez-novak-studentka-slovenscine-54157.html (1. oktober 2019).

Antić Gaber, M. in Kuhar, R. (2018). Identitetna gibanja in politike spola in seksualnosti v Sloveniji. V R. Kuhar (ur.), Identitete na presečǐ̌ču kriz (101-122). Ljubljana: Filozofska fakulteta.

Božič, K. (2018). Naš spol je ženski. Večer (31. 5. 2018). Dostopno prek

https://www.vecer.com/na-ljubljanski-filozofski-fakulteti-nas-spol-je-zenski-6484191 (1. oktober 2019).

Butler, J. (1993). Bodies that Matter. London in New York: Routledge.

Dobrovoljc, H. in Stabej, M. (2019). Jezikovne izbire v slovenskih smernicah za spolno občutljivo rabo jezika. Slavistična revija, 67(2), str. 373-384.

Drnovšek Zorko, H. (2019). Razumevanje spolno nevtralne rabe jezika. (27. 3. 2019.) Dostopno prek https://www.cep.si/wp-content/uploads/2019/ 03/Perspectives_DZorko_27.3.2.pdf (1. oktober 2019) 
Erlich, S. in King, R. (1992). Gender-Based Language Reform and the Social Construction of Meaning. Discourse and Society, 3(2), 151-166. doi: 10.1177/0957926592003002002

Formanowicz, M. M., Cisłak, A., Horvath, L. K. in Sczesny, S. (2015). Capturing socially motivated linguistic change: how the use of gender-fair language affects support for social initiatives in Austria and Poland. Front. Psychol. 6:1617. doi: 10.3389/fpsyg.2015.01617 [Marie Curie Initial Training Network - Language, Cognition, and Gender, ITN LCG, http:// www.itn-lcg.psy.unibe.ch/content/index_eng.html]

Gary, A. O. in Faigley, L. (1991). Language, Politics, and Composition: Noam Chomsky interviewed by Journal of Advanced Composition, 11(1). Dostopno prek https://chomsky.info/1991

Gastil, J. (1990). Generic pronouns and sexist language: the oxymoronic character of masculine generics. Sex Roles, 23(11), 629-643.

Godina Vuk, V. (2018a). Kako globoko so padli tovarišice in tovariši humanisti na FF. Fokuspokus (13. 6. 2018). Dostopno prek https://fokuspokus.si/ article/3111?=kako-globoko-so-padli-tovarisice-in-tovarisi-humanisti-na-ff

Godina Vuk, V. (2018b). Praksa, ki izključuje. Obrazi (12. 7. 2018).

Gomboc, M. (2018). Izjava Komisije za enake možnosti na področju znanosti o primeru vključujoče prakse - uporabe ženskega slovničnega spola v pravnih aktih Filozofske fakultete Univerze v Ljubljani (Ministrstvo za izobraževanje, znanost in šport, 15. 11. 2018). Dostopno prek http://www.mizs.gov.si/fileadmin/mizs.gov.si/pageuploads/novice/pdf/ Izjava_Komisije_uporaba_zenske_spolne_oblike_v_pravilnikih_FF_UL.pdf

Gorjanc, V. (2018). Okrogla miza Jezik in spol na FF UL 23. 10. 2018. Dostopno prek https://www.youtube.com/watch?v=3DhQQzpoHzA

Haraway, D. (1991). Simians, Cyborgs, and Women. The Reinvention of Nature. New York: Routledge.

M. Hellinger in Bussmann H. (ur.). (2001). Gender across languages: the linguistic representation of women and men. Amsterdam, New York: John Benjamins.

Holmes, J. (1997a). Women, language and identity. Journal of Sociolinguistics, 2, 195-223. 
Holmes, J. (1997b). Story-telling in New Zealand women's and men's talk. V R. Wodak (ur.), Gender, discourse and ideology, str. 263-293. London: Sage. Jager, V. (2018). Strašni novi svet. Mladina (6. 7. 2018). Dostopno prek https://www.mladina.si/186361/strasni-novi-svet/

Jalušič, J. (2002). Kako smo hodile na feministično gimnazijo. Ljubljana: Založba /cf*.

Jogan, M. (2018). Izključevanje žensk iz ustvarjanja razumskosti. Dnevnik (18. 8. 2018). Dostopno prek https://www.dnevnik.si/1042836602/ slovenija/ izkljucevanje-zensk-iz-ustvarjanja-razumskosti

Kalin Golob, M. (2018a). Okrogla miza Jezik in spol na FF UL 23. oktober 2018. Dostopno prek https://www.youtube.com/watch?v=3DhQQzpoHzA

Kalin Golob, M. (2018b). Intervju (V. Jager) v Mladini z dne 6. 7. 2018. Dostopno prek https://www.mladina.si/186361/strasni-novi-svet/

Kalin Golob, M. in Lengar Verovnik, T. (2019). Spol med družbo, jezikovno rabo in predpisom. Slavistična revija, 67(2), 385-394.

Kern, B. in Vičar, B. (2019). Jezik in transspolne identitete. Slavistična revija, 67(2), 413-422.

Kuhar, R. (2018a). Okrogla miza Jezik in spol na FF UL 23. 10. 2018. Dostopno prek https://www.youtube.com/watch?v=3DhQQzpoHzA

Kuhar, R. (2018b). Marija Novak, študent slovenščine (odziv na članek K. Ahačiča »Janez Novak, študentka slovenščine «). Spletna stran Filozofske fakultete (28. 5. 2018). Dostopno prek http://www.ff.uni-lj.si/ node/11631

Kunst Gnamuš, O. (1994/95). Razmerje med spolom kot potezo reference in spolom kot slovnično kategorijo. Jezik in slovstvo, 4O(7), 255-62.

Marinčič, M. (2018). Študentka, ki postane oče. Delo (9. 6. 2018). Dostopno prek http://www.delo.si/sobotna-priloga/studentka-ki-postane-oce-59105.html

Martyna, W. (1978). What Does 'He' Mean? Use of the Generic Masculine. Journal of Communication, 28(1), 131-138.

Marušič, L. (2018). Jezik in družbena neenakost: Metka je študentka in to bi rad postal tudi Janez. Dnevnikov objektiv. Dostopno prek https://www. dnevnik.si/1042834413

Marvin, T. (2018a). Jezik in spol. Kvarkadabra. Dostopno prek https://kvarkadabra.net/2018/o6/jezik-in-spol/ 
Marvin, T. (2018b). Jezik in spol. Delo. Dostopno prek https://www.delo.si/mnenja/gostujoce-pero/jezik-in-spol-67662.html

Marvin, T. (2019). O predvidljivosti slovnične kategorije spola v slovenščini. Slavistična revija, 67(2), 151-158.

Metina lista. Dostopno prek https://metinalista.si/pregled-leta-2018-zenske-v-casopisnih-medijih/; https://metinalista.si/category/meta-dekleta/zenske_v_medijih/

Močnik, R. (2018). Okrogla miza Jezik in spol na FF UL 23. 10. 2018. Dostopno prek https://www.youtube.com/watch?v=3DhQQzpoHzA

Močnik, R. (2019). Identitetna politika na univerzi. Slavistična revija, 67(2), 355-360.

Motchenbacher, H. (2010). Language, Gender and Sexual Identity: Poststructuralist Perspectives. Amsterdam, Philadelphia: John Benjamins.

Motschenbacher, H. (2016). A poststructural approach to structural gender linguistics. V J. Abbou in F. H. Baider (ur.), Gender, Language and the Periphery: Grammatical and social gender from the margins (65-88). Amsterdam, Philadelphia: Benjamins.

Moulton, J., Robinson, G. M. in Elias, C. (1978). Sex Bias in Language Use: 'Neutral' Pronouns That Aren't. American Psychologist, 33(11), 1032-1036.

Muršič, R. (2018). Ženski spol na filozofski fakulteti. Dnevnik (5. 6. 2018). Dostopno prek https://www.dnevnik.si/1042824518

Novak, A. B. (2018a). Okrogla miza Jezik in spol na FF UL 23. 10. 2018. Dostopno prek https://www.youtube.com/watch?v=3DhQQzpoHzA

Novak, A. B. (2018b). Izjava komisije za slovenščino v javni rabi. Komisija za slovenščino v javni rabi. Slovenska akademija znanosti in umetnosti.

Orešnik, J. (2015). Naravna skladnja. SAZU. RAZRED ZA FILOLOŠKE IN LITERARNE VEDE, 65.

Plahuta Simčič, V. (2018). Odpravljal naj bi seksizem, zbuja pa neslane kvante. Dnevnik (30. 5. 2018). Dostopno prek http://www.delo.si/ novice/ slovenija/odpravljal-naj-bi-seksizem-zbuja-pa-neslane-kvante-55465.html

Sarrasin, O., Gabriel, U. in Gygax, P. (2012). Sexism and attitudes toward gender-neutral language. The case of English, French, and German. Swiss J. Psychol, 71, 113-124. doi: 10.1024/1421-0185/a0o0078 
Sczesny, S., Formanowicz, M. in Moser, F. (2016). Can Gender-Fair Language Reduce Gender Stereotyping and Discrimination? Frontiers in Psychology. Language Sciences. Dostopno prek https://www.frontiersin.org/ articles/10.3389/fpsyg.2016.00025/full

Slavistična revija (67(2), posebna številka). Dostopno prek https://srl.si/ojs/srl/ issue/view/2019-2

Služba vlade Republike Slovenije za zakonodajo: Nomotehnične smernice za področje pravnih predpisov (2004/2008/2018). Dostopno prek https:// www.gov.si/assets/vladne-sluzbe/SVZ/f5odof6d15/ Nomotehnicne_smernice-2018.pdf

Smolej, M. (2019). Anormativizem in dileme normativne slovnice. Slavistična revija, 67(2), 179-188.

Stabej, M. (2018a). Okrogla miza Jezik in spol na FF UL 23. 10. 2018. Dostopno prek https://www.youtube.com/watch?v=3DhQQzpoHzA

Stabej, M. (2018b). Očitek, da posegamo $v$ slovenski jezik, je iz trte izvit Mladina (Intervju, M. Horvat). Dostopno prek https://www.mladina.si/185878/ dr-marko-stabej-ocitek-da-posegamo-v-slovenski-jezik-je-iz-trte-izvit/

Šauperl, M. in Jeram, J. (2018). Smernice za spolno občutljivo rabo jezika. SSEM. Ljubljana: Ministrstvo za delo, družino, socialne zadeve in enake možnosti.

Šorli, M. (2018a). Okrogla miza Jezik in spol na FF UL 23. 10. 2018. Dostopno prek https://www.youtube.com/watch?v=3DhQQzpoHzA

Šorli, M. (2018b). Lepo je, da smo vključevalni, nerodno pa, da smo to zgolj takrat, ko nam ustreza. Metina lista (12. 6. 2018). Dostopno prek https://metinalista.si/ lepo-je-da-smo-vkljucevalni-nerodno-pa-da-smo-to-zgolj-takrat-ko-nam-ustreza/

Šribar, R. (2010). Interne smernice za spolno občutljivo rabo jezika. Ljubljana: Komisija za ženske v znanosti.

Šribar, R. (2018a). Okrogla miza Jezik in spol na FF UL 23. 10. 2018. Dostopno prek https://www.youtube.com/watch?v=3DhQQzpoHzA

Šribar, R. (2018b). Šale z jezikom in o njem so lahko duhovite, če ga najprej vzameš zares. Dnevnik (16. 6. 2018). Dostopno prek https://www.dnevnik.si/1042825826/mnenja/odprta-stran/ sale-z-jezikom-in-o-njem-so-lahko-duhovite-ce-ga-najprej-vzames-zares 
Šribar, R. (2018c). (Ne)odgovorna znanost: svoboda dela in verjetje v režim. Dialogi, 1O(2018). Dostopno prek http://www.aristej.si/slo/PDF/ Dialogi\%20 10\%2018\%20Uvod.pdf

Štumberger, S. (2018). Transspolnost v slovenščini: Bomo nekoč pisali »povabili_e so ga_jo k sodelovanju«? Portal PLUS. Dostopno prek https:// www.portalplus.si/2668/uvajanje-podcrtaja-za-izrazanje-spolne-nebinarnosti/

Štumberger, S. (2019). Neumnosti s spolom: Aktivisti bi zdaj spreminjali pravopis, uvajali obvezno uporabo ženskega spola. Portalplus (6. 6. 2019). Dostopno prek https://www.portalplus.si/3285/posvet-o-spoljenju/

Transakcija. (2017). Priročnik za medijsko poročanje o transspolnosti (6. 11. 2017). Dostopno prek http://transakcija.si/medijski-prirocnik/ pogosti-primeri-slabih-praks-in-spostljive-alternative/

Tuldava, J. (1998). Probleme un Metoden der quantitativ-systemischen Lexicologie [1987 v ruskem izvirniku]. Trier: Wissenschaftlicher Verlag.

Vidovič Muha, A. (2019). Spol - jezikovni sistem in ideologija. Slavistična revija, 67(2), 127-137.

Wikiverza (2018). Izražanje spolne nebinarnosti. Pregled prispevkov po datumu objave. Dostopno prek https://sl.wikiversity.org/wiki/ Izra\% 5 \% BEanje_spolne_nebinarnosti

Wilson, E. in Ng, S. H. (1988). Sex Bias in Visual Images Evoked by Generics: A New Zealand Study. Sex Roles, 18(3/4), 159-168.

Zimman, (2014). The Discursive Construction of Sex. V L. Zimman in dr. (ur.), Queer Excursions (str. 13-34). Oxford: Oxford University Press. Žagar, Ž. I. in Milharčič Hladnik, M. (1996). Nekaj izhodiščnih prizadevanj za odpravo seksistične rabe jezika. V L. Bogovič in Z. Skušek (ur.), Spol: $\check{Z}$ (str. XX-YY). Ljubljana: Studia Humanitatis.

Žele, A. (2019). Spol v predikaciji. Slavistična revija, 67(2), 141-149. 


\section{AT ONE'S WITS' END WITH LANGUAGE AND GENDER: BETWEEN GRAMMAR AND IDEOLOGY}

The present text revisits the public debate that followed the passing of "Decision 41 " by the Senate of the Faculty of Arts, University of Ljubljana, on a language policy introducing gender-sensitive language use in the Faculty's administrative documents. The debate attracted public attention and media interest for several months, culminating in a Round Table on Gender and Language, which took place at the UL Faculty of Arts almost exactly one year ago, on 23 October 2018. While re-evaluating the views expressed in the debate from a temporal distance, this paper is an attempt to continue the debate on gender categories and gender identities, focusing on androcentricity in language. In addition to highlighting the theoretical background that is (or should be) the driving force of the debate, we also performed a simple statistical analysis of the collected opinions and responses by media representation and gender representation. In the qualitative part of the analysis, we were primarily interested in which (apparent) expert and ideological oppositions fuelled the specific rhetoric and discourse adopted in the debate.

Keywords: gender-sensitive language use, androcentricity, discourse

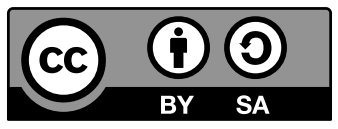

To delo je ponujeno pod licenco Creative Commons: Priznanje avtorstva-Deljenje pod enakimi pogoji 4.o Mednarodna. / This work is licensed under the Creative Commons Attribution-ShareAlike 4.o International.

https://creativecommons.org/licenses/by-sa/4.o/ 